\title{
Effects of Hollow Sizes on the Properties of Sandcrete Blocks
}

\author{
${ }^{* 1}$ Olagunju, O.S. and ${ }^{2}$ Raheem, A.A. \\ ${ }^{1}$ Alshaya Group, 91316 Road, Al Barsha Al Barsha 1 - Dubai, United Arab Emirates \\ ${ }^{2}$ Department of Civil Engineering, Ladoke Akintola University of Technology, Ogbomoso, Nigeria.
}

*Corresponding Author: olawoleolagunju89@gmail.com

Tel : +971553926130

Submitted on: 10/09/2021

Accepted on: 30/09/2021

\begin{abstract}
Two-cell hollow sandcrete blocks constitute the dominant wall construction material for modern shelter in many African countries, especially Nigeria. The hollow cavities in the block have adverse effect on its mechanical characteristics. This study investigated the effects of hollow sizes on the properties of sandcrete blocks. Sandcrete blocks of size $225 \times 225 \times 450 \mathrm{~mm}$ with varying hollow sizes of $175 \times 187.5,173 \times 190$ and $180 \times 210 \mathrm{~mm}$ and web thickness 25,35 and $15 \mathrm{~mm}$ respectively; were produced using cement: sand ratio of 1:12. The blocks were tested for compressive strength, density and water absorption. The results indicated that compressive strength at 28 days for blocks with hollow sizes $175 \times 187.5,173 \times 190$ and 180 $\times 210 \mathrm{~mm}$ are 5.22, 3.64 and $0.41 \mathrm{Nmm}^{-2}$ respectively. The corresponding densities are 2307.56, 2589.15 and $1715.23 \mathrm{~kg} / \mathrm{m}^{3}$ while the rate of water absorption are $22.2,18.8$ and $24.5 \%$, respectively. It was concluded that the larger the size of the hollow in sandcrete blocks the lower their mechanical properties.
\end{abstract}

Keywords: Sandcrete blocks, Hollow size, Compressive strength, Density, Water absorption.

\section{Introduction}

For as long as civilization started, man has been committed to the use of bricks for the primary purpose of building and sun-dried bricks were used extensively in ancient Egyptian civilization. During construction, the bricks were often made of clay and usually mixed together with straws in order to achieve extra strength while drying (Omirin, 1988). According to Raheem et al., (2012), clay bricks have been an important component of building in Nigeria even long before the advent of sandcrete blocks, especially in the Southwestern zone of the country. The increase in human population, together with rapid increase in the standard of living of the populace resulted in the need for proper housing and these have led to the change in the taste from the use of bricks to that of blocks (Baiden and Tuuli, 2004).

Sandcrete block is the most commonly used walling unit in South-South region of Nigeria due to heavy rains usually experienced in that part of the country which made earth block technology unpopular (Ewa et al., 2013). According to Deverkey (2001), hollow sandcrete blocks have several advantages amongst which are: they can be made larger than solid blocks, and if lightweight aggregate is used, can be very light, without forfeiting much of their load-bearing capacity; they require far less mortar than solid blocks and construction of walls is easier and quicker; the voids can be filled with steel bars and concrete, achieving high seismic resistance; the air-space provides good thermal insulation, which is of advantage in most climatic regions, except warm-humid zones and the cavities can be used as ducts for electrical installation and plumbing.

Consequently, an investigation into block making factories in Nigeria by Mohammed (1992) revealed that the geometry of hollow sizes in sandcrete blocks vary, because of the variation in the cavity sizes and centre 
- web to end -web ratios. These variations ultimately produce variation in the axial compressive strength of sandcrete blocks (Ezeokonkwo, 2000). According to Ewa and Ukpata (2013), the overall effects of cavity size on the strength of sandcrete blocks is required in the production of quality blocks, as it has been shown that the strength of a block is a function of its average solid thickness.

Several sandcrete block producers mostly tampered with the sizes of the hollow in order to save materials thereby reducing production cost. This action is however injurious to the quality of the end product in terms of strength and durability characteristics. Omoregie and Alutu (2006) stated that fragile sandcrete blocks may fail to exhibit the required quality performance. Therefore, this study investigated the effects of hollow sizes on the properties of sandcrete blocks.

\section{Materials and Methods}

The materials used for this study are sharp sand, cement and water. Clean sharp sand was collected within the campus of Ladoke Akintola University of Technology (LAUTECH), Ogbomoso, Oyo State and the sand was sieved using a wire mesh of diameter $6 \mathrm{~mm}$. This is necessary to remove solid impurities like nylon and wood, while the sand was also washed with clean water to remove clay particles and soluble salts. The sand was then graded to uniformity with BS 882 (1983).

Ordinary Portland Cement (OPC) manufactured by West African Cement Company, Ewekoro Ogun State was obtained locally from retailers. The water was collected from a tap in the Geotechnical Laboratory of Department of Civil Engineering, LAUTECH, Ogbomoso, Oyo State. The following preliminary tests were carried out on the materials used: sieve analysis and moisture content.

\section{Sieve analysis}

Sieve analysis of the sand was used to determine the grading of the soil sample in accordance with procedure in BS 1377 (1990).

\section{Moisture content}

Moisture content is the amount of water expressed as a proportion by mass of the dry solid particles. It was carried out using oven drying method in accordance with the provisions in BS 1377 (1990).

Moisture Content $=\quad \frac{100 \text { (mass of water) }}{(\text { mass of dry soil })} \quad \%$

\section{Fabrication of Block Moulds of Different Hollow Sizes}

The metal moulds used for producing the blocks with different hollow sizes were fabricated at the Metal workshop of LAUTECH, Ogbomoso. The block size considered is $225 \times 225 \times 450 \mathrm{~mm}$. The metal moulds were constructed with varying hollow sizes of $175 \times 187.5,173 \times 190$ and $180 \times 210 \mathrm{~mm}$ and web thickness 25, 35 and $15 \mathrm{~mm}$ respectively. Figures 1, 2 and 3 show the fabricated respectively. 


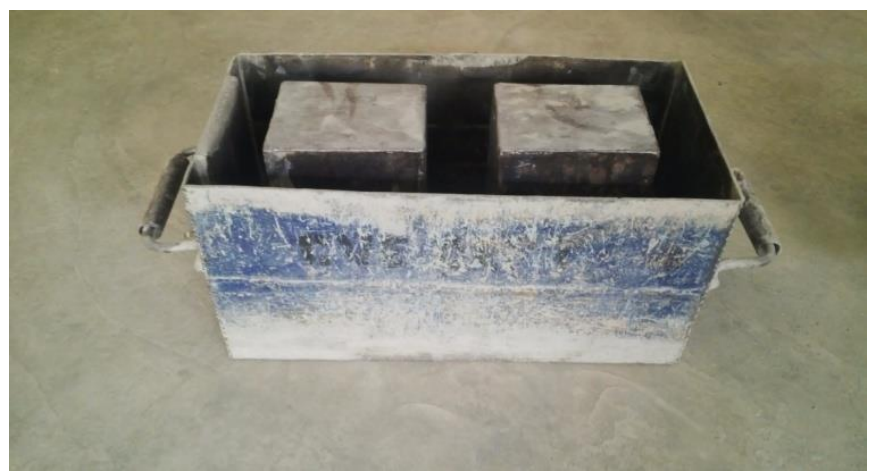

Figure 1: $225 \mathrm{~mm} \times 225 \mathrm{~mm} \times 450 \mathrm{~mm}$ block with hollow size of $187.5 \times 175 \mathrm{~mm}$

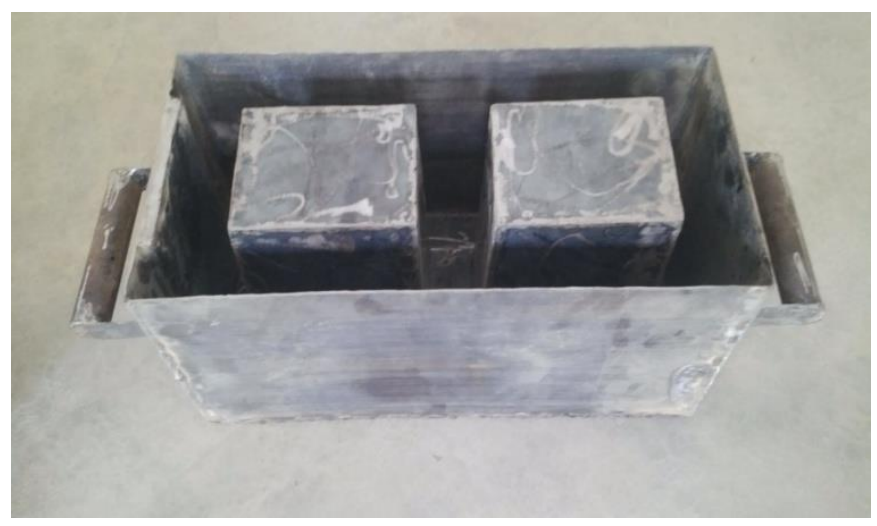

Figure 2: $225 \mathrm{~mm} \times 225 \mathrm{~mm} \times 450 \mathrm{~mm}$ block with hollow size of $173 \times 190 \mathrm{~mm}$

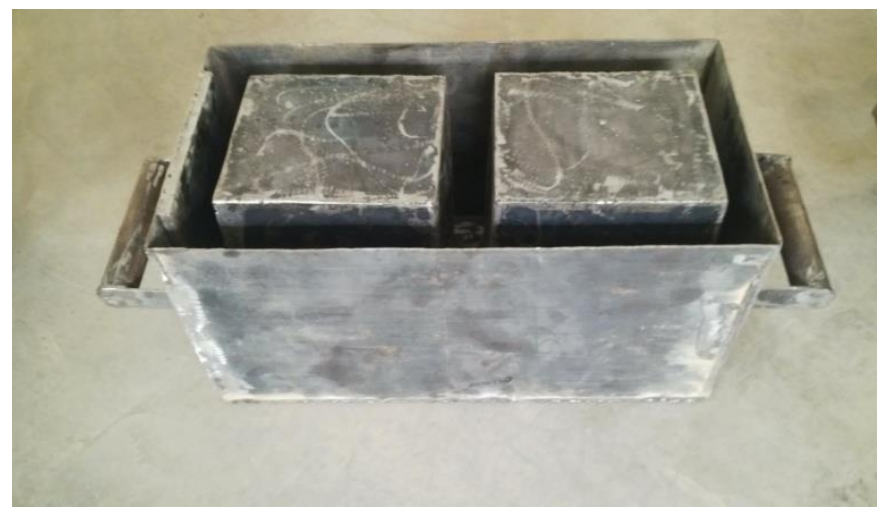

Figure 3: $225 \mathrm{~mm} \times 225 \mathrm{~mm} \times 450 \mathrm{~mm}$ block with hollow size of $180 \times 210 \mathrm{~mm}$

\section{Production of hollow sandcrete blocks}

The production of the hollow sandcrete blocks for this study was done at the Structural Engineering Laboratory of Civil Engineering Department, LAUTECH Ogbomoso. The mix proportion adopted was one part of OPC to twelve parts of clean sand (1:12). The cement and sand were thoroughly mixed together to ensure even distribution of the cement with the sand. Only sufficient water to enable the hydration of the cement was used. The water was judged to be adequate when a quantity of the mixture pressed between the 
palms caked without bringing out water (Raheem, 2006). The mixture was placed inside the metal mould under consideration and compacted by compression and vibration for 1 minute. Thereafter, the mould was gently lifted up and the block with the wooden pellet on which it was laid, carefully placed in nearby open space for curing. The method of curing employed was wetting the blocks with water twice daily and the curing was performed for 28days.

\section{Testing of sandcrete blocks}

Three tests which have direct bearing with the investigation of the effects of hollow sizes on the properties of sandcrete blocks were conducted in this study. They are: compressive strength, density and water absorption tests.

Compressive strength test: The compressive strengths of the blocks were determined at curing ages 3, 7, 14, 21 and 28 days. The test was carried out in accordance with the provisions in NIS 87 (2007). The strength tests were performed on an electrically operated compression testing machine of the Seidner model which has a maximum capacity of $1500 \mathrm{KN}$ crushing load. The crushing load obtained from the machine was divided by the net area of hollow sandcrete blocks to obtain the compressive strength in N/mm ${ }^{2}$.

Density determination: The measurement of each block was carried out noting the length, width and height, while the dimensions of the holes were also taken. At each curing age, the weight of each block was measured and the density of each block is given as:

$$
D=m / v
$$

Where:

$\mathrm{D}=$ Density in $\mathrm{kg} / \mathrm{m}^{3}$

$\mathrm{m}=$ Mass of the block in $\mathrm{Kg}$

$\mathrm{v}=$ Net Volume of Block in $\mathrm{m}^{3}$ which is = Net Area $\mathrm{x}$ Height

Net Area $=$ Gross area of block - Area of holes

Water absorption test: This was done to test the dimensional stability of hollow sandcrete blocks. After curing for 28 days to gain maximum strength, block specimens were sun-dried until there is no further reduction in their dry weights $\left(\mathrm{W}_{1}\right)$ and then completely soaked in water for moisture uptake for 24 hours. Thereafter, the specimens were removed, mopped and their weights $\left(\mathrm{W}_{2}\right)$ measured using semi-automatic balance (Raheem and Sulaimon, 2013). Water absorption was then expressed as the change in weight of the specimens over the initial weight and expressed as follows:

$$
W A=\frac{W_{2}-W_{1}}{W_{1}} \times 100 \%
$$

Where:

$$
\begin{aligned}
& \text { WA }=\text { Water absorption } \\
& W_{1}=\text { Initial weight } \\
& W_{2}=\text { Final weight }
\end{aligned}
$$


LAUTECH Journal of Civil and Environmental Studies

Volume 7, Issue 2; September, 2021

\section{Results and Discussion}

The results obtained from the various tests are now discussed.

\section{Sieve analysis}

The sieve analysis result for the sharp sand used is as presented in Figures 4. It could be observed from the grading curve that the coefficient of uniformity $(\mathrm{cu})$ and coefficient of curvature (cc) for the sand are 2.52 and 0.78 respectively. This is an indication that the sand is well graded and therefore suitable for use in the production of sandcrete blocks.

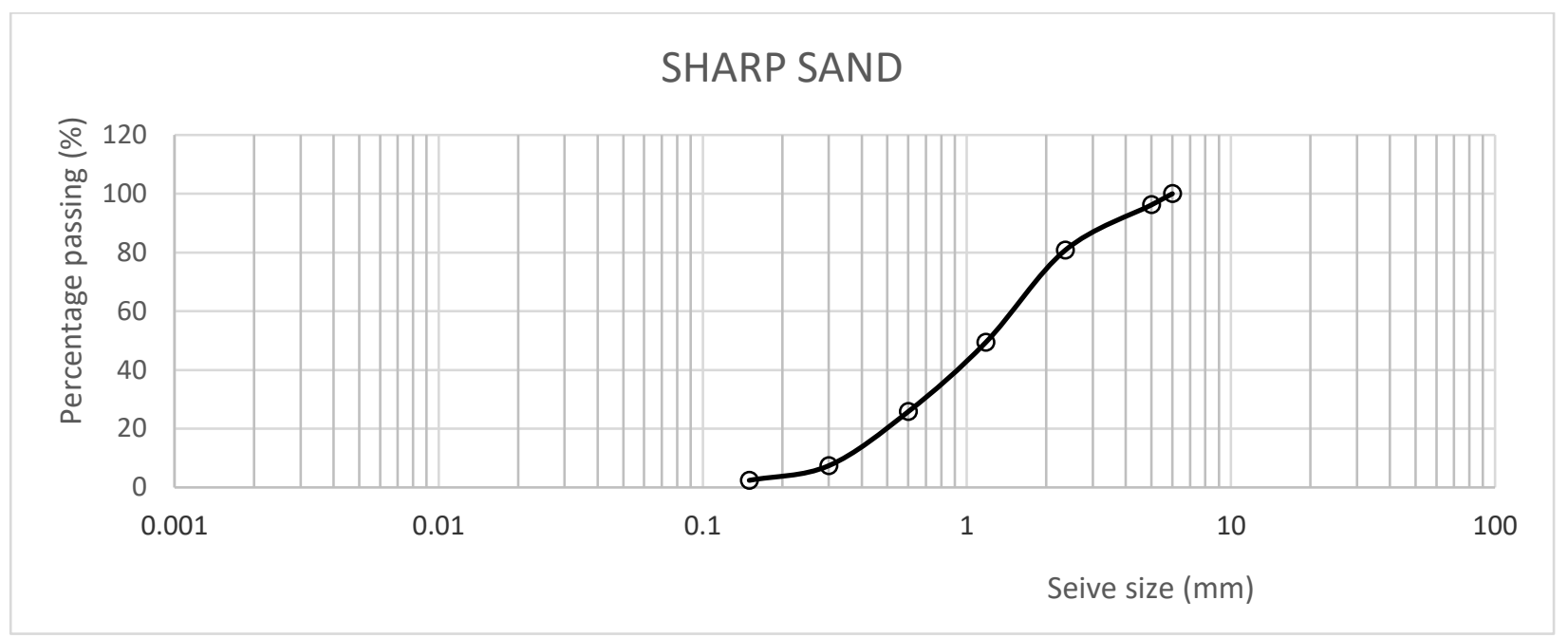

Figure 4: Grading curve for sharp sand

\section{Moisture content}

The result of the moisture content of sharp sand as obtained from Table 1 is $9.47 \%$. The result is within the acceptable value of 8-15\% natural moisture content specified by BS 1377 (1990). This value is required to be able to know the amount of water to be added when mixing the sand and cement together.

\section{Density}

The density of sandcrete blocks with hollow sizes $175 \times 187.5,173 \times 190$ and $180 \times 210 \mathrm{~mm}$ are as presented in Figure 4 to 6, respectively. It can be observed from Figure 4 that the density of blocks with hollow size $175 \times 187.5$ and web thickness $25 \mathrm{~mm}$ ranged from 2008.14 to $2307.56 \mathrm{~kg} / \mathrm{m}^{3}$. From Figure 5 , the density of blocks with hollow size $173 \times 190$ and $35 \mathrm{~mm}$ web thickness ranged from 2431.76 to $2589.15 \mathrm{~kg} / \mathrm{m}^{3}$. The density for blocks with hollow size $180 \times 210 \mathrm{~mm}$ and $15 \mathrm{~mm}$ web thickness as obtained from Figure 6 range from 1548.61 to $1715.23 \mathrm{~kg} / \mathrm{m}^{3}$. These results indicated that the thicker the web, the higher the density of the block. Also, the density of blocks with web thickness of 25 and $35 \mathrm{~mm}$ are higher than those recorded by Raheem et al. (2012) where the density of $225 \mathrm{~mm}$ blocks ranges from 2002.21 to $2203.03 \mathrm{~kg} / \mathrm{m}^{3}$ as well 
as those of Raheem (2006) which range from 2073.5 to $2166.3 \mathrm{~kg} / \mathrm{m}^{3}$. Blocks with web thickness of $15 \mathrm{~mm}$ have very low densities not comparable with any previous studies.

Table 1: $\quad$ Moisture Content of Sharp Sand

\begin{tabular}{cllll}
\hline Container No & 1 & 2 & 3 & 4 \\
\hline Mass of cup + wet sand & 104.86 & 105.90 & 89.30 & 82.95 \\
Mass of cup + dry sand & 98.35 & 99.25 & 84.00 & 78.40 \\
Mass of cup & 29.55 & 22.25 & 29.20 & 29.25 \\
Mass of dry soil & 68.80 & 70.40 & 54.80 & 49.15 \\
Mass of water & 6.51 & 6.65 & 5.30 & 4.55 \\
Water content & 9.46 & 9.45 & 9.67 & 9.26 \\
Average water content & & & $\mathbf{9 . 4 7}$ & \\
\hline
\end{tabular}

The Nigerian Building and Road Research Institute (NBRRI) proposed a minimum density of $2210 \mathrm{~kg} / \mathrm{m}^{3}$ for standard blocks (NIS 87, 2007). Thus, only blocks with hollow size $173 \times 190 \mathrm{~mm}$ and $35 \mathrm{~mm}$ web thickness satisfied the minimum requirements at all ages while blocks with web thickness of $25 \mathrm{~mm}$ met the minimum at 28 days only.

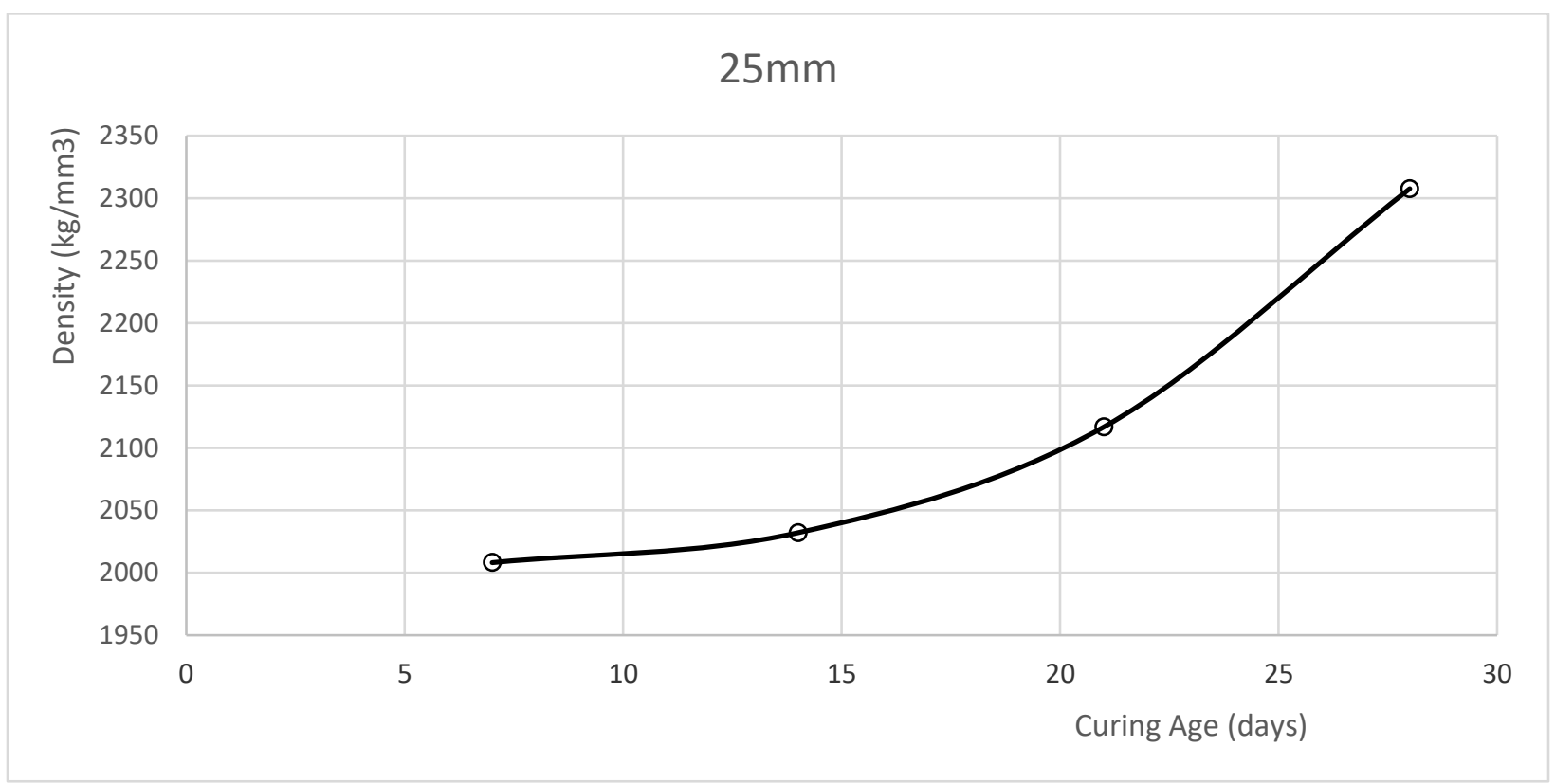

Figure 4.: Density of blocks with hollow size $175 \mathrm{~mm} \times 187.5 \mathrm{~mm}$ and web thickness $25 \mathrm{~mm}$ 


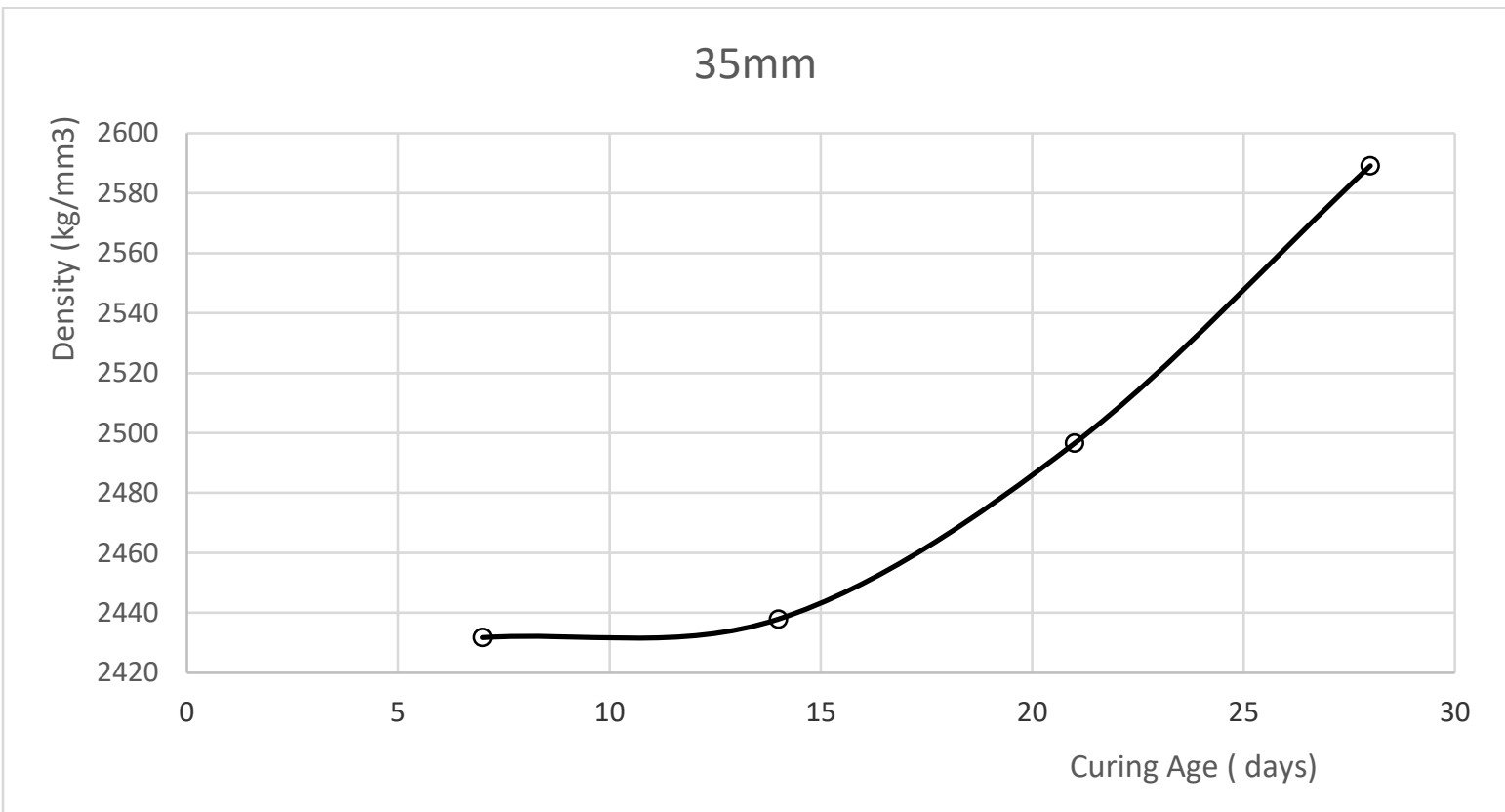

Figure 5: Density of blocks with hollow size $173 \times 190 \mathrm{~mm}$ and web thickness $35 \mathrm{~mm}$

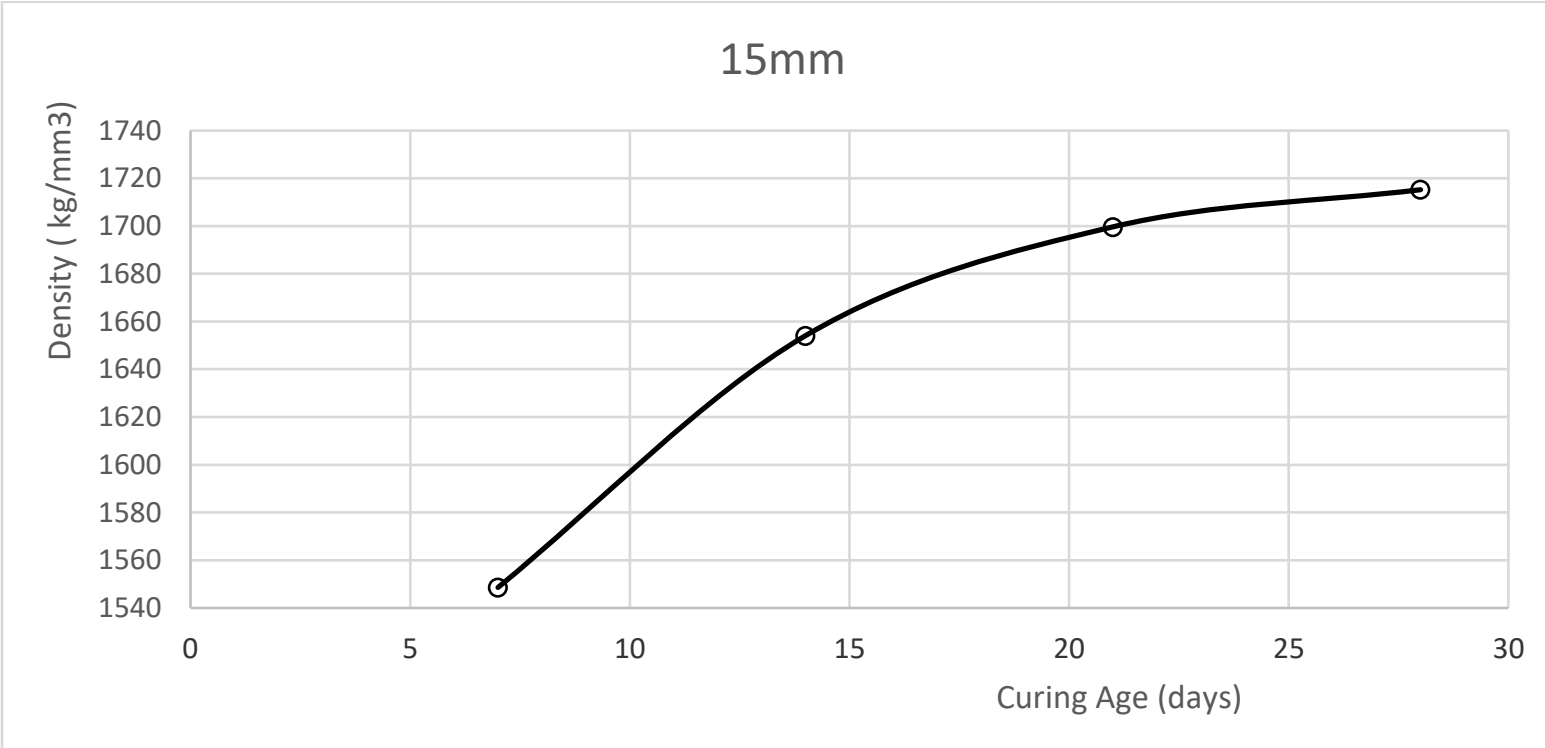

Figure 6: Density of blocks with hollow size $180 \times 210 \mathrm{~mm}$ and web thickness $15 \mathrm{~mm}$

\section{Compressive strength}

The compressive strength of sandcrete blocks with hollow sizes $175 \times 187.5,173 \times 190$ and $180 \times 210 \mathrm{~mm}$ are as presented in Figure 7 to 9, respectively. As observed from Figure 7, the compressive strength of sandcrete hollow blocks with hollow size $175 \times 187.5 \mathrm{~mm}$ varied from $1.70 \mathrm{~N} / \mathrm{mm}^{2}$ at 7 days to $5.22 \mathrm{~N} / \mathrm{mm}^{2}$ at 28 days. For blocks with hollow sizes $173 \times 190$ and $180 \times 210 \mathrm{~mm}$, Figure 8 and 9 indicated that their compressive strength varied from 1.46 to $3.64 \mathrm{~N} / \mathrm{mm}^{2}$ and 0.21 to $0.41 \mathrm{~N} / \mathrm{mm}^{2}$ as curing ages increased from 7 to 28 days, respectively. The minimum 28 days compressive strength of $3.40 \mathrm{~N} / \mathrm{mm}^{2}$ stipulated by 
Nigerian Industrial Standard (NIS 87: 2007) for $225 \mathrm{~mm}$ sandcrete hollow blocks, was satisfied by the blocks with hollow sizes of $175 \times 187.5 \mathrm{~mm}$ and $173 \times 190 \mathrm{~mm}$ only. These results are also in tandem with those obtained by Raheem et al. (2012) and Ewa and Ukpata (2013). The compressive strength of blocks with hollow size $180 \times 210 \mathrm{~mm}$ are rather too low and do not meet up with the minimum required in any standard. Thus, sandcrete blocks with hollow size of $180 \times 210 \mathrm{~mm}$ are not recommended for use on any construction site.

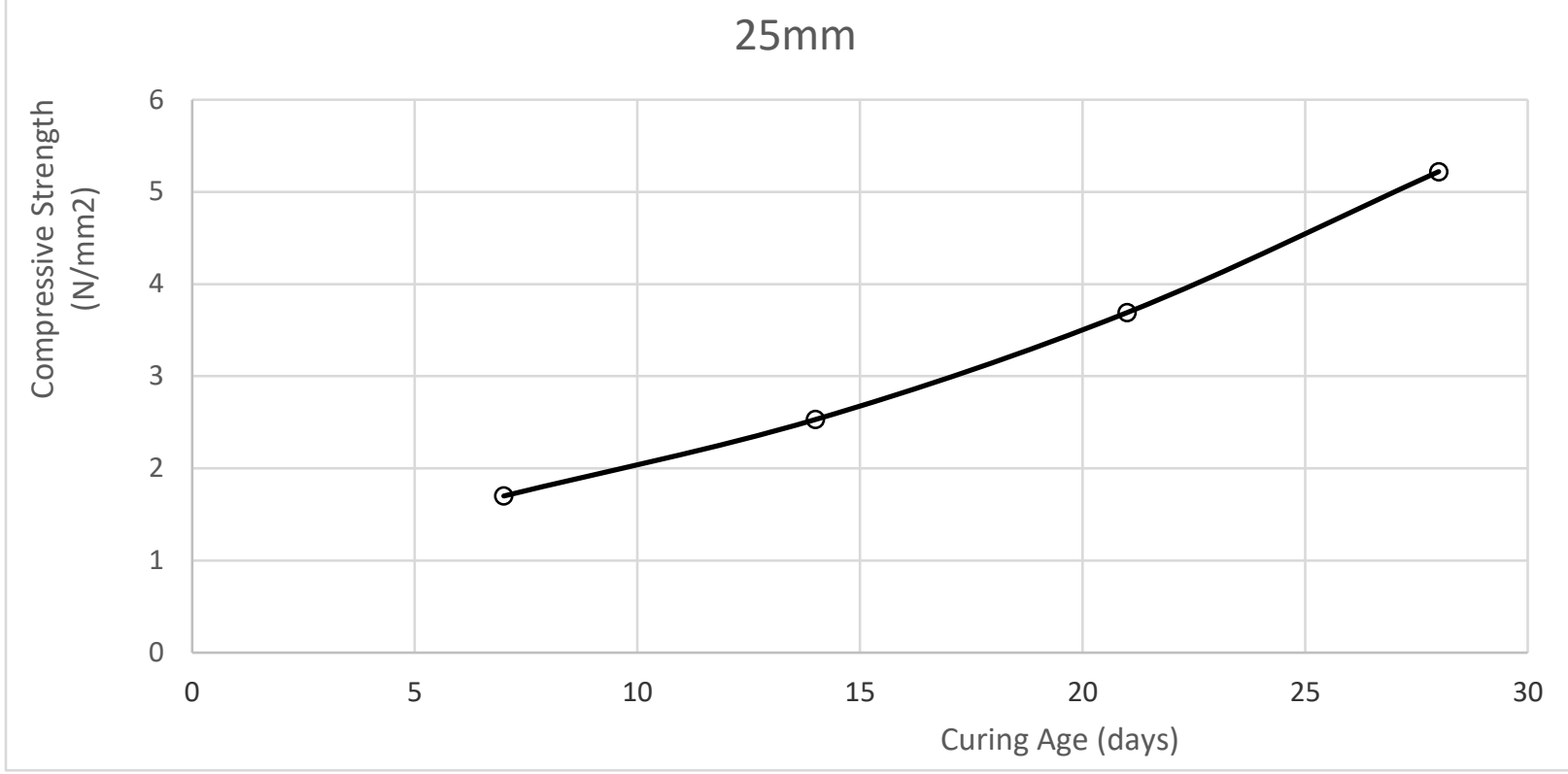

Figure 7: Compressive strength of sandcrete blocks with hollow size $175 \mathrm{~mm} \times 187.5 \mathrm{~mm}$

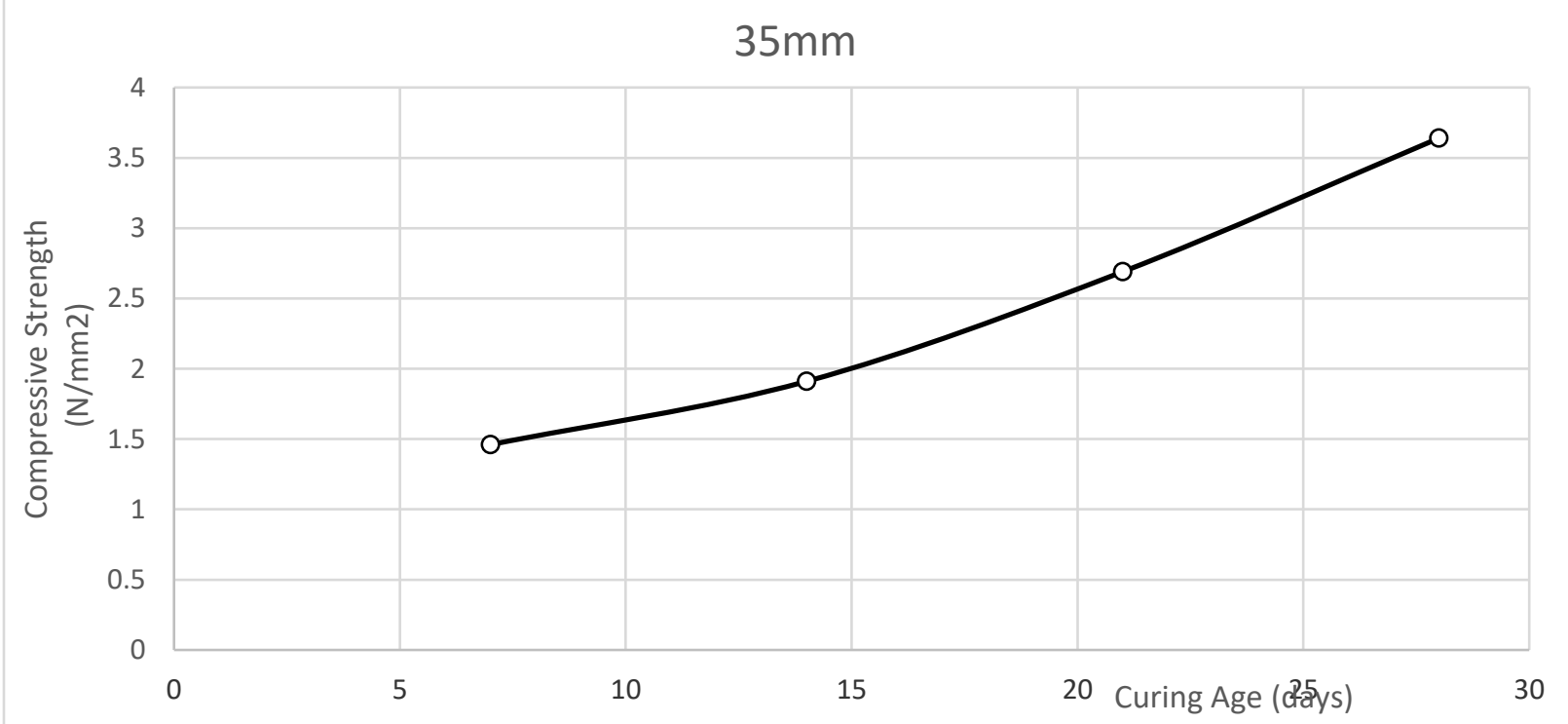

Figure 8: Compressive strength of sandcrete blocks with hollow size $173 \times 190 \mathrm{~mm}$ 


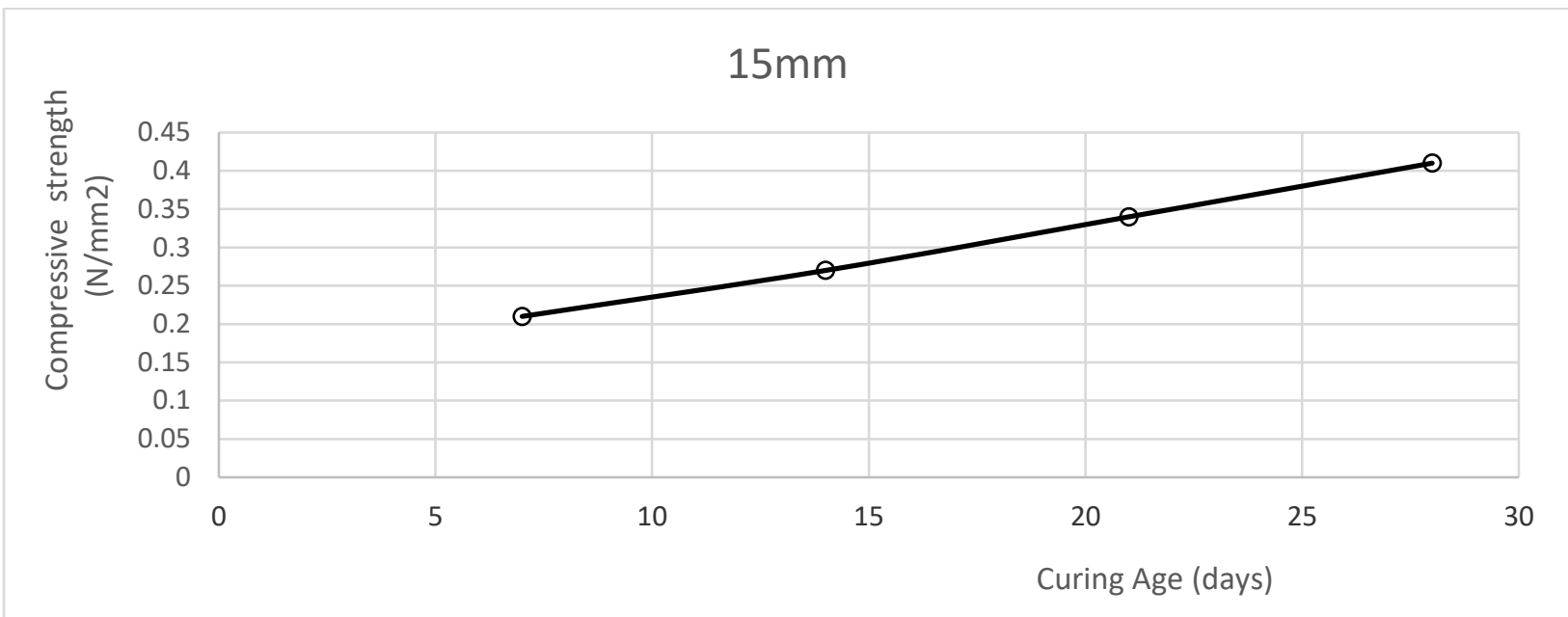

Figure 9: Compressive strength of sandcrete blocks with hollow size $180 \times 210 \mathrm{~mm}$

\section{Water absorption}

The results obtained for water absorption of sandcrete blocks with hollow sizes $175 \times 187.5,173 \times 190$ and $180 \times 210 \mathrm{~mm}$ with web thickness of 25,35 and $15 \mathrm{~mm}$, respectively are presented in Table 2 . The average rate of absorption for 15, 25 and $35 \mathrm{~mm}$ web thickness are 24.5, 22.2 and 18.8\%, respectively. This shows that the higher the web thickness, the lower the water absorbed since thicker webs indicate smaller hollow sizes.

Table 2: Water absorption of sandcrete hollow blocks

\begin{tabular}{|c|c|c|c|c|}
\hline $\begin{array}{c}\text { Web Thickness } \\
(\mathrm{mm})\end{array}$ & $\begin{array}{c}\text { Initial weight }\left(\mathrm{w}_{1}\right) \\
(\mathrm{Kg})\end{array}$ & $\begin{array}{c}\text { Final weight }\left(\mathrm{w}_{2}\right) \\
(\mathrm{Kg})\end{array}$ & $\begin{array}{c}\text { W.A } \\
\%\end{array}$ & $\begin{array}{l}\text { Average } \\
\text { W.A \% }\end{array}$ \\
\hline 15 & $\begin{array}{ll}\text { 1. } & 18.9 \\
\text { 2. } & 19.8 \\
\text { 3. } & 19.0\end{array}$ & $\begin{array}{l}23.9 \\
24.1 \\
23.8\end{array}$ & $\begin{array}{l}26.5 \\
21.7 \\
25.3\end{array}$ & 24.5 \\
\hline 25 & $\begin{array}{ll}\text { 1. } & 27.0 \\
\text { 2. } & 27.1 \\
\text { 3. } & 27.3\end{array}$ & $\begin{array}{l}33.1 \\
33.4 \\
33.0\end{array}$ & $\begin{array}{l}22.6 \\
23.2 \\
20.9\end{array}$ & 22.2 \\
\hline 35 & $\begin{array}{ll}\text { 1. } & 28.7 \\
\text { 2. } & 29.3 \\
\text { 3. } & 28.6\end{array}$ & $\begin{array}{l}33.7 \\
34.3 \\
34.9\end{array}$ & $\begin{array}{l}17.4 \\
17.1 \\
22.0\end{array}$ & 18.8 \\
\hline
\end{tabular}

This water absorption rate is higher than $16.95 \%$ obtained by Anosike and Oyebade (2011) and the acceptable value of 12\% according to BS 5628: Part 1: 2005. This could be as a result of the manual method of block production which does not allow for adequate vibration to fill the pores of the blocks.

\section{Conclusions}

From the findings in this study, it could be concluded that the sizes of hollows in sandcrete blocks have significant influence on the characteristics of the blocks in terms of density, compressive strength and water absorption. Large hollow sizes are preferred by block producers due to savings in materials cost, these have 
adverse effects on the properties of the blocks thereby reducing its quality. In order to use sandcrete hollow blocks as a structural material in walls, the minimum standards on size of the hollow specified by National Building Code (2006) and NIS 87 (2007) should be strictly adhered to for the safety of the work force and occupants of the building.

\section{References}

Anosike, M.N and Oyebade A.A (2011) Sandcrete Blocks and Quality Management in Nigeria Building Industry, Journal of Engineering, Project and Production Management, 2(1): 37-46.

Baiden, B., and Tuuli, M., (2004). Impact of Quality Control Practice in Sandcrete Blocks Production. Journal of Architectural, Engineering, (10), 53 - 60.

British Standards Institution (2005) Code of Practice for the use of Masonry, BS 5628: Part 1, British Standards Institution, London.

British Standards Institution (1990) Methods of Test for the Classification of Soil and for the Determination of Basic Physical Properties, BS 1377, British Standard Institution, London.

Ewa, D.E, and Ukpata, J.O., (2013). Investigation of the Compressive Strength of Commercial Sandcrete Blocks in Calabar, Nigeria. International Journal of Engineering and Technology, 3, (4), 477 - 482.

Ewa, D.E, and Ukpata, J.O. and Etika, A. A. (2013). Effects of Curing on the Compressive Strengths of Commercial Sandcrete Blocks in Calabar Nigeria, International Journal of Engineering and Technology, 3, (7), $716-729$.

Ezeokonkwo, J.C., (2000). Influence of Orientation and Size of Voids on Concrete Cub Strength. Journal of Architectural Engineering, (3), 65 - 75.

Mohammed, M., (1992). The Quality of Sandcrete Hollow Blocks produced in Kano State, Unpublished M.Sc. Thesis, Ahmadu Bello University, Zaria.

N.B.R.R.I (2006). N.B.R.R.I Interlocking Block-Making Machine. Journal of Construction, 1; $\quad$ (1), 15 17.

National Building Code (2006). "Building Regulations", LexisNexis Butterworths, Ohio. NIS 87, (2007). Standard for Sandcrete Blocks. Nigerian Industrial Standard Approved by Standard Organization of Nigeria, Lagos.

Omirin, A.O., (1988). Building Construction Using Bricks. Unpublished B.Sc. Report, Department of Civil Engineering, University of Ibadan, 31 - 42.

Omoregie, A.G., and Alutu, O.E., (2006). The Influence of Fine Aggregate Combinations on Particle Size Distribution, Grading Parameters and Compressive Strength of Sandcrete Blocks. Canadian Journal of Civil Engineering, 4; (2), 100 - 126.

Raheem, A. A. (2006) "Comparism of the Quality of Sandcrete Blocks Produced by LAUTECH Block Industry with others within Ogbomoso Township", Science Focus, 11 (1), 103-108.

Raheem, A.A., Momoh, A.K., and Soyingbe, A.A., (2012). Comparative Analysis of Sandcrete Hollow Blocks and Laterite Interlocking Blocks as Walling Elements. International Journal of Sustainable Construction Engineering and Technology, 3 (1), 79 - 88.

Raheem, A. A. and Sulaiman, O. K. (2013) Saw Dust Ash as Partial Replacement for Cement in the Production of Sandcrete Hollow Blocks, International Journal of Engineering Research and Applications (IJERA) 3 (4), 713-721. 